\title{
A COMPARISON OF CROATIAN AND SLOVENIAN EXONYMS
}

Drago Kladnik, Ivana Crljenko, Ankica Čilaš Šimpraga, Matjaž Geršič

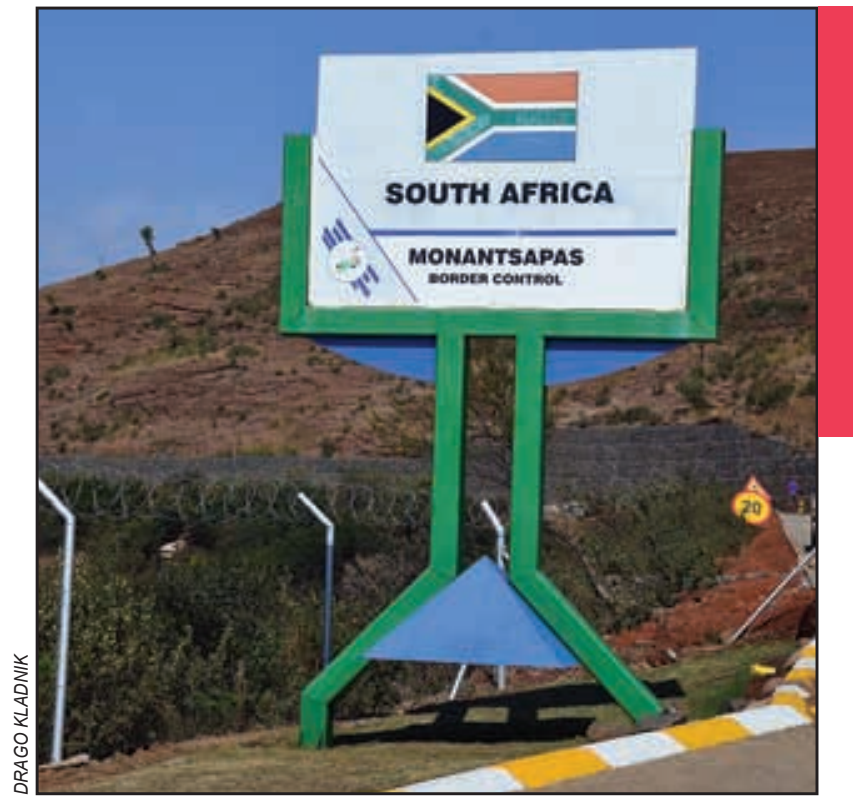

The names for South Africa in Croatian and Slovenian are completely different exonyms. The photo shows a border crossing with Lesotho. 


\section{A Comparison of Croatian and Slovenian exonyms}

DOI: http://dx.doi.org/10.3986/AGS.4653

UDC: $91: 811.163 .6373 .21$

91:811.163.42'373.21

COBISS: 1.01

ABSTRACT: Croatian and Slovenian are very closely related South Slavic languages, but during their historical development they came under the influence of various other languages and various language policies determined by the broader framework of Hungary and Austria. This fact makes the comparative study of exonymization in both languages very interesting. Croatian and Slovenian exonyms are not only part of the cultural heritage of both nations, but also part of global cultural heritage. The article presents a comparative analysis of exonyms in both languages carried out as part of a bilateral project lasting a year and a half. The analysis is based on an improved typology, which was adjusted to the manner of exonymization for borrowed foreign geographical names in both of these related languages.

KEY WORDS: exonym, country name, intangible cultural heritage, Croatia, Slovenia

The article was submitted on $10^{\text {th }}$ July, 2016.

ADDRESSES:

Drago Kladnik, Ph.D.

Anton Melik Geographical Institute

Research Center of the Slovenian Academy of Sciences and Arts

Gosposka ulica 13, SI-1000 Ljubljana, Slovenia

E-mail: drago.kladnik@zrc-sazu.si

Ivana Crljenko, Ph.D.

Miroslav Krleža Institute of Lexicography

Frankopanska 26, HR-10000 Zagreb

E-mail: ivana.crljenko@lzmk.hr

\section{Ankica Čilaš Šimpraga, Ph.D.}

Institute for Croatian Language and Linguistics

Republike Austrije 16, HR-10000 Zagreb

E-mail: acilas@ihjj.hr

\section{Matjaž Geršič, Ph.D.}

Anton Melik Geographical Institute

Research Center of the Slovenian Academy of Sciences and Arts

Gosposka ulica 13, SI-1000 Ljubljana, Slovenia

E-mail: mgersic@zrc-sazu.si 


\section{Introduction}

Croatian and Slovenian are very closely related South Slavic languages (Comrie, Matthews and Polinsky 1999; Šekli 2013), but during their historical development they came under the influence of various other languages and various language policies determined by the broader framework of Hungary and Austria (Weber 2013). This fact makes the comparative study of exonymization in both languages very interesting.

Exonyms are part of the vocabulary of every language (Kadmon 1997; Kladnik et al. 2013), and their use changes constantly, just like the language itself. Therefore, it is vital to know the role of exonyms in both Slovenian and Croatian. Exonyms are an important component of both languages and thus not only part of the cultural heritage of both nations, but also part of global cultural heritage.

Although exonyms have already been studied in both Slovenian (e.g., Kladnik 2007, 2009; Kladnik and Bole 2012; Perko and Kladnik 2017) and Croatian (e.g., Crljenko 2014), this article presents the first comparative analysis of this linguistic phenomenon.

\section{Methods}

The Croatian-Slovenian bilateral project presented below lasted a year and a half, which was too brief for the participating researchers to carry out a comprehensive analysis of exonyms in the two languages. This was especially due to the fact that only Slovenian exonyms had been systematically collected and processed up until that point. Croatian researchers are relying on the Slovenian researchers' experience and their systematically arranged The Gazetteer of Slovenian Exonyms (Internet 1; Kladnik and Perko 2013; Kladnik and Geršič 2014).

Croatian researchers also revised the Croatian exonyms listed in Slovenian list of exonyms. The Croatian exonyms that do not have a corresponding Slovenian exonym and are only used as endonyms in Croatian are missing from the gazetteer. On the other hand, it also includes several Slovenian exonmys without a corresponding Croatian exonym.

Because it is impossible to compile a comparable detailed collection of Croatian exonyms (Crljenko 2016) in the short time available during the project (in Slovenia eighteen comprehensive sources were consulted), the Croatian researchers opted for a thematically differentiated approach. Hence, they began by collecting the names of the continents, countries, capital cities, and dependent territories, followed by the names of regions and certain major natural geographical features, such as hydronyms, as well as cities. The Croatian exonyms included in the text are based also on data available from Wikipedia.

We developed a typology of country names with six possible combinations of results from their comparative analysis. Throughout, we paid particular attention to the existing Slovenian typology of exonymization (Kladnik et al. 2013: 68-70; Kladnik and Perko 2013) and also tested its applicability in Croatian. This led us to improve the methodology for the missing category and to look for suitable examples of exonymization for all categories in both languages, which could be identical, could differ, or could appear in only one of the two languages.

Exonyms were mainly collected from atlases and professional literature dating from the second half of the nineteenth century to the Second World War. The first Slovenian atlas was prepared by the editor Matej Cigale, who issued it in individual volumes (Cigale 1869-1877; Fridl et al. 2005). At that time, only Kozenn's high-school atlas had been published in Croatian (Kozen 1887; Blasius Kozenn (in Slovenian Blaž Kocen) was a major cartographer with Slovenian roots, active in Moravia and Vienna). This atlas was also used by Slovenian high-school students in the absence of other such literature. A full twenty editions of this atlas were published in Croatia between 1887 and 1943 (Bratec Mrvar et al. 2011, 105; Crljenko 2014).

\section{Croatian-Slovenian bilateral project}

The main purposes of the project were:

a) to establish a unique exonym classification typology according to the intensity and variety of name adaptation, and 
b) to analyze various social, political, and linguistic influences on different process of adaptation (exonymization) in two closely related South Slavic languages (Crljenko 2016). Comparing Croatian and Slovenian exonmys provides a basis for analyzing the motives for exonymization in the early stages of adapting foreign geographical names.

Among the goals of their research efforts, the researchers working on this project in both countries also highlighted the presentation of the project and its preliminary findings at the Zagreb conference of the Working Group on Exonyms (Kladnik 2015) and the joint preparation of research articles.

Informally, the paths of both research teams had already crossed prior to this, while preparing seminal lexical works in both countries (i.e., general world atlases, school atlases, and encyclopedias), in which the use of exonyms adapted to international UN resolutions, their proper transcription, and the appropriate transcription of endonyms (taking into account the applicable romanization systems in the case of their transliteration into the Roman alphabet) are key for successfully implementing projects.

\section{Main results}

A quick overview of exonyms in both languages reveals that many of them are completely identical, that some only differ in details, and that the ones that differ significantly in both languages account for the smallest share. Examples of the last group are provided in Table 1. The papers that have been prepared by the project partners address the strength of influences on the exonymization process in both languages and investigate differences between them.

Table 1: Comparison of selected Croatian and Slovenian exonyms that differ significantly.

\begin{tabular}{|c|c|c|c|}
\hline Endonym & Semantic type & Croatian exonym & Slovenian exonym \\
\hline Arctica & region & Arktik & Arktika \\
\hline Bălgariija & country & Bugarska & Bolgarija \\
\hline Brasil & country & Brazil & Brazilija \\
\hline France & country & Francuska & Francija \\
\hline Zhōngguó & country & Kina & Kitajska \\
\hline Côte d'Ivoire & country & Obala Bjelokosti/Bjelokosna Obala & Slonokoščena obala \\
\hline Muang Thai & country & Tajland & Tajska \\
\hline Algérie / al-Jazāiir / Dzayer & country & Alžir & Alžirija \\
\hline Elláda & country & Grčka & Grčija \\
\hline Guiné-Bissau & country & Gvineja Bisau & Gvineja Bissau \\
\hline Wien & settlement & Beč & Dunaj \\
\hline Venezia & settlement & Venecija & Benetke \\
\hline Napoli & settlement & Napulj & Neapelj \\
\hline Bucureşti & settlement & Bukurešt & Bukarešta \\
\hline Rio Amazonas / Solimões & land hydronym & Amazona & Amazonka \\
\hline Rhein / Rhin / Rijn & land hydronym & Rajna & Ren \\
\hline Lake Huron & land hydronym & Huron & Huronsko jezero \\
\hline Český les / Böhmischer Wald & land relief form & Češka šuma & Češki gozd \\
\hline Rocky Mountains & land relief form & Stjenjak & Skalno gorovje \\
\hline Ostriv Zmiyinyy / Insula şerpilor & island relief form & Zmijski otok & Kačji otok \\
\hline Victoria Island / Kitlineq & island relief form & Otok Victoria & Viktorijin otok \\
\hline
\end{tabular}

A second aspect of comparison focuses on studying the types of adaptation of exonyms in the two languages. Here it is necessary to observe that both geographers and linguists deal with exonyms in Croatia, whereas in Slovenia this is almost exclusively the domain of geographers. Several typologies have already been prepared in Slovenia, but none of them have been tested by linguistic experts. Cooperation between linguists in the Croatian-Slovenian research group is an excellent aid in creating a better typology that could be used to compare the features of exonyms in the two languages. Because the meetings of the UNGEGN Working Group on Exonyms have shown interest in such a universally applicable classification, this would also be useful for the categorization of exonyms in other related languages. 
The basic research on the most recent and best-developed version of the Slovenian exonymization types (Kladnik and Geršič 2014) showed that the existing types are also perfectly acceptable for analyzing Croatian exonyms. Additional findings by the Croatian linguists confirmed the Slovenian research efforts to date that have not yet been adequately analyzed by Slovenian linguists. Their detailed analyses revealed the need to add another type to the existent exonymization types, which in terms of the degree of exonymization is ranked eighth (labeled $\mathrm{H}$ ):

Phonetic form of roots with Croatianized and Slovenianized endings from the Latin suffixes -ia, -ea (Ide. *- iā-, *-ēa). This group includes names of some countries, continents, major regions, islands, and island groups, which are usually formed from roots adapted to Croatian/Slovenian pronunciation and the Croatianized/Slovenianized ending -ija or -eja, which derives from the Latin suffixes -ia and -ea. Examples: Cro: Australija, Sln: Avstralija »Australia«; Sln: Španija »Spain« (España); Sln: Francija »France«; Cro: Austrija, Sln: Avstrija »Austria» (Österreich); Cro/Sln: Eritreja »Eritrea» ('Ertrā/Iritrīyā); Cro/Sln: Gvineja »Guinea " (Guinée); Cro/Sln: Belgija »Belgium« (België/Belgique); Cro/Sln: Azija »Asia«; Cro/Sln: Cezareja »Caesarea«; Cro/Sln: Lombardija »Lombardy« (Lombardia); Cro/Sln: Sicilija »Sicily« (Sicilia); Cro/Sln: Katalonija "Catalonia« (Cataluña/Catalunya); Cro/Sln: Tasmanija »Tasmania«, and Cro/Sln: Polinezija »Polynesia«.

Together, we developed a new shared typification based on Moder's classification (Moder 1972), which includes twelve types instead of eleven that are ordered from the smallest to greatest degree of exonymization:

A. Exonym from translated common name and original proper name. Typical examples are the following names: Cro: jezero Titicaca»Lake Titicaca» (Lago Titicaca); Cro: vrh Windom»Windom Peak«; Cro: planina Kenya »Mount Kenya (Kirinyaga/ Mount Kenya); Cro: rt Henry»Cape Henry«; Sln: otoki Bounty, Cro: otočje Bounty»Bounty Islands«; Sln: globel Meteor »Meteor Deep«; Sln: hrbet Sala y Gómez "Sala y Gómez Ridge" (Cadena de Sala y Gómez); Sln: jezero Hanka "Lake Khanka " (ozero Xanka); Sln: mizasta gora Sylvania »Sylvania Tablemount/Bikini Guyot«; Sln: plošča Nazca »Nazca Plate«; Sln: prelom GOFAR »GOFAR Fracture Zone«; Sln: rt Correnti »Cape Correnti« (Capo delle Correnti); Sln: zemeljska ožina Kra »Kra Isthmus/Isthmus of Kra» (Khokhok Kra).

B. Exonym from translated common name and more or less Croatianized/Slovenianized proper name. Typical examples: Cro: nizina Gangesa »Ganges Plain«; Cro: delta Inda »Indus Delta«; Cro: poluotok Aljaska »Alaska Peninsula«; Sln: gora Fudži »Mount Fuji« (Fujisan); Sln: jarek Ob»Ob Trench«; Sln: jezero Abaja "Lake Abaya " (Abaya Hayk); Sln: oaza Karga »Kharga Oasis« (el-Karga); Sln: gora Kenija "Mount Kenya" (Kirinyaga/ Mount Kenya); Sln: polotok Šantung "Shandong Peninsula" (Shāndōng Bàndăo); Sln: rt Komorin »Kanyakumari« (Kanniyākumāri); Sln: slana puščava Lut »Lut Desert» (Dasht-e Lüt); Sln: prekop Majna-Donava, Cro: kanal Majna-Dunav »Main-Danube Canal« (Main-DonauKanal); Cro/Sln: jezero Tanganjika »Lake Tanganyika/Lac Tanganyika «.

C. Exonym from adopted secondary original name. These include geographical names that differ from the official original names and can be borrowed in an unchanged, non-adapted form as colonial names, names from the past, names in the neighbouring languages, and names from Slavic languages. Since they became widely used, they have been used exclusively or largely in this version, whereas the official forms of the names are only used for their unambiguous identification. Typical examples of this type of adaptation include the following names: Cro: Pečuh »Pécs«; Sln: Benares »Varanasi « (Vārānasi); Sln: Bistrica »Haliacmon River« (Haliákmōn); Sln: El Obeid»Al-Ubayyid» (Al Ubayyid); Sln: Harkov »Kharkiv«; Sln: Kanton »Guangzhou« (Guăngzhōu); Sln: Lemnos (Limnos); Sln: Sinkiang »Xinjiang» (Xīnjiāng); Sln: Tripolis »Tripoli« (Țarābulus); Cro/Sln: Armenija »Armenia« (Hayastan); Cro/Sln: Cejlon "Sri Lanka" (Śrī laṃkāva); Cro/Sln: Peking »Beijing « (Běijīng); Cro/Sln: Kijev »Kiev«(Kyïv). Cro/Sln: Kosovska Mitrovica »Kosovska Mitrovica» (Mitrovicë); Cro/Sln: Tirana (Tiranë).

D. Exonym from original name with omitted special characters and diacritics. Also in this adaptation type, the main principle is to remain as faithful to the original form as possible, but here the main issue is the letter, accent, and diacritics, which are omitted due to simplifications in printing and tradition, but here the main issue is that a letter, accent or diacritic is omitted due to simplifications in Croatian/ Slovenian printing, tradition, and pronunciation. For example Sln: Reykjavik»Reykjavík «(Reykjavík); Sln: Gdansk»Gdańsk « (Gdańsk); Sln: Narjan Mar »Naryan-Mar « (Nyar'yana marq); Cro/Sln: Iran »Iran « (İān); Cro/Sln: Riga »Riga» (Rìga); Cro/Sln: Bogota »Bogotá« (Bogotá); Cro/Sln: Islamabad »Islamabad « (Islämabād); Cro/Sln: Sana »Sana’a» (Șan»ä«); Cro/Sln: Agadir »Agadir» (Aǵadìr).

E. Exonym from transliterated original name with simplified letters and diacritics. This includes a large group of names that are transferred from non-Roman scripts (e.g., Cyrillic, Arabic, Hebrew, Devanagari, 
Chinese, and Japanese) into the Roman alphabet. In this process, we skip the intermediary language (French, English, German, and Russian) and any unusual phonetic representation $(s h, s c h, c h=\check{s}$; oo, $o u=u$ ); for example, we write Cro/Sln: Pandžab instead of Punjab, Cro/Sln: Sečuan instead of Sichuan/ Szechwan (Sìchuān Shěng). We also omit any long or short syllables markings, as already mentioned with the Roman alphabet: for example Cro: Juba, Sln: Džuba»Juba « (Dzhūbā); Cro/Sln: Asuan (Aswān); Cro/Sln: Tokio (Tokyō); Cro/Sln: Bengazi »Benghazi« (Binġāzì). Even greater adaptation linked to the written form has become common in the pronunciation of these names. They are pronounced like Slovenian or Croatian names, without any foreign flavour.

F. Exonym from transcribed original name with Croatianized/Slovenianized ending. This group of exonyms is composed of »hybrids « partly resulting from the Croatianization/Slovenianization tendencies present in the previous two groups. It includes names with a Croatianized/Slovenianized ending (e.g., Tirana [Tiranë]), the root (e.g., in the pronunciation of Cro/Sln: Ostende »Ostend «[Oostende]), especially if the root is commonly known (e.g., from a personal name, e.g. Sln: Ptolemaida [Ptolemais/Tolmeta/ $\bar{A}$ thār Țulmaythah]) or it does not belong to the same language group (Indian and Spanish cities in North America, and native names in the former British, French, Portuguese, and Spanish colonies. They also include names such as Cro: Prag, Sln: Praga »Prague« (Praha); Cro/Sln: Pariz»Paris«; Cro/Sln: Varšava »Warsaw» (Warzsawa). The following basic principle applies to the entire group: the better the name is known, the longer it is present in Slovenian consciousness, and the more frequently it is used, the smaller the likelihood that its pronunciation will strictly copy the original form; instead it is simplified (especially the endings), which makes it easier to decline and to form its adjectival form.

G. Exonym from borrowed and adapted name. This group includes names borrowed from another language, Croationized/Slovenianized, and adapted to Croatian/Slovenian pronunciation (e.g., Cro/Sln: Abesinija »Abyssinia « [from Italian Abissinia]) or Croatian/Slovenian usage: Sln: Šensi »Shanxi Province« (Shănxī Shěng); Sln: Velika Vlaška »Wallachia Mayor/Muntenia» (Țara Românească); Sln: Hongkong »Hong Kong» (Xiānggăng); Sln: Peč »Peć« (Pejë/Peja); Sln: Kašgar»Kashgar» (Käshí/Qeşqer); Sln: Japonske Alpe »Japanese Alps« (Nihon Arupusu); Sln: Mizijski Olimp»Mysian Olympus« (Uludağ); Cro: Dnjestar, Sln: Dnester »Dniester ( Dnister/Nistru); Sln: Spitsbergi »Svalbard «; Cro/Sln: Nahičevan »Nakhchivan « (Naxçıvan); Cro/Sln: Irtiš »Irtyš« (Irtyš/Ertis/É ěrqísỉ hé).

$\mathrm{H}$. Exonym with phonetic form of the roots and Croationized/Slovenianized endings from the Latin suffixes -ia, -ea (Ide. ${ }^{*}$-iā-, ${ }^{\star}$-ēa) (already described in detail above).

I. Exonym with phonetic form of the root and Croatian/Slovenian ending (like -ska/-ška/-čka, -je, -i etc.). The next stage of adaptation is best seen in the names of numerous countries, continents, settlements, regions, and island groups. Here, an ideal harmony is achieved between the foreign root and Slovenian pronunciation, which means that the root is written completely phonetically and the endings are completely Croatian or Slovenian. Examples: Cro: Francuska »France» (France); Sln: Portugalska »Portugal«; Sln: Pomorjanska »Pomerania» (Pommern/Pomorze); Sln: Kurili »Kuril/Kurile Islands« (Kuril'skie ostrova/Chishima-rettō); Sln: Porenje, Cro: Porajnje »Rhineland «(Rheinland); Cro: Falačka, Sln: Pfalška »Palatinate« (Pfalz); Cro: Bukarešt, Sln: Bukarešta »Bucharest « (Bucureşti); Cro/Sln: Afrika »Africa«; Cro/Sln: Amerika »America«; Cro/Sln: Bretanja »Brittany« (Bretagne); Cro/Sln: Apalači »Appalachians/Appalachian Mountains«; Cro/Sln: Pireneji »Pyrenees« (Pirineos/Pyrénées).

J. Exonym from fully translated name. This group includes full translations of endonyms. This stage no longer involves original official names that preserve the root, but only in the semantic sense. Examples: Sln: Skalno gorovje »Rocky Mountains«; Sln: Plitvina lososov »Salmon Bank«; Cro: Crveno more, Sln: Rdeče morje »Red Sea " (al-Bahr al-Ahmar); Cro: Rt dobre nade, Sln: Rt dobrega upanja »Cape of Good Hope«; Cro/Sln: Nizozemska »Netherlands« (Nederland); Cro/Sln: Veliko slano jezero »Great Salt Lake«. These names also include generally and partly borrowed foreign names, such as Sln: Pacifik»Pacific«; Sln: Mediteran »Mediterranean ", and roots of heavily Croationized/Slovenianized geographical names, such as Cro: Novi Zeland, Sln: Nova Zelandija »New Zealand «; Cro: Zapadna Australija, Sln: Zahodna Avstralija »Western Australia «; Cro: Zapadnosibirska nizina, Sln: Zahodnosibirsko nižavje »West Siberian Plain« (Zapadno-Sibirskaja ravnina); Cro/Sln: Nova Škotska »Nova Scotia«.

K. Exonym from traditionally Croationized/Slovenianized name with a trace of the original root. This group is comprised of names in which the root can still be traced in places. Examples: the exonym Sln: Lipnica »Leibnitz«; Cro: Firenca, Sln: Firence »Florence« (Firenze); Cro: Konstantinopol, Sln: Konstantinopel »Constantinople« (Konstantinopolis/Constantinopolis); Cro/Sln: Apulija »Apulia» (Puglia); Cro/Sln: Rim »Rome» (Roma). 
L. Exonym from Croatian/Slovenian name. In the last group the root can no longer be traced because the names have been developed in Croatian or Slovenian themselves (due to their historical connections with the named places). Typical examples include Cro: Jakin »Ancona«; Sln: Celovec »Klagenfurt«; Sln: Videm »Udine«; Cro: Beč, Sln: Dunaj»Vienna» (Wien); Cro: Mleci, Sln: Benetke»Venice» (Venezia); Cro: Željezno, Sln: Železno »Eisenstadt«; Cro/Sln: Carigrad»Istanbul« (İstanbul).

\subsection{Comparison of country names}

Because the Croatian partners have not yet completed the selection of all exonyms from all available sources, we made a comparison based only on the semantic type "country names." We divided these into six different groups adapted to the data:

- Endonym;

- Endonym in only one of the two languages;

- Same endonym in both languages;

- Minor differences in exonymization (difference in capitalization or individual letters);

- Major differences (different ending or different root, several different letters, different translation of generic component); and

- Different name.

Based on the comparison, we determined (Figures 1 and 2) that nearly half of the country names in the two languages use the same exonym. In terms of numbers, these are followed by completely different names (e.g., Cro: Kina vs. Sln: Kitajska »China»), names with major differences in the degree of exonymization (e.g., Cro: Španjolska vs. Sln: Španija »Spain«), names with minor (only orthographic) differences in the degree of exonymization (e.g., Cro: Austrija vs. Sln: Avstrija "Austria»), and country names for which both languages use the endonym (e.g., Cro/Sln: Angola), followed distantly by country names for which the endonym is used in only one of the two languages - while in the other a translation of conjunction is used (e.g. Cro: Bosna i Hercegovina vs. Sln: Bosna in Hercegovina »Bosnia and Herzegovina«).

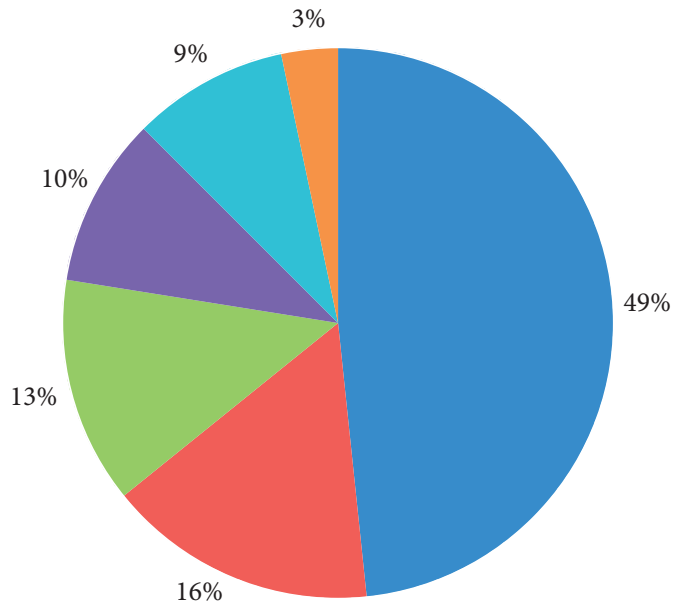

Same exonym in both languages

Different name

Major differences in exonymization

Minor differences in exonymization

Endonym

Endonym in only one of two languages

Figure 1: Share of names by groups base on a comparison between their names in Croatian and Slovenian. 


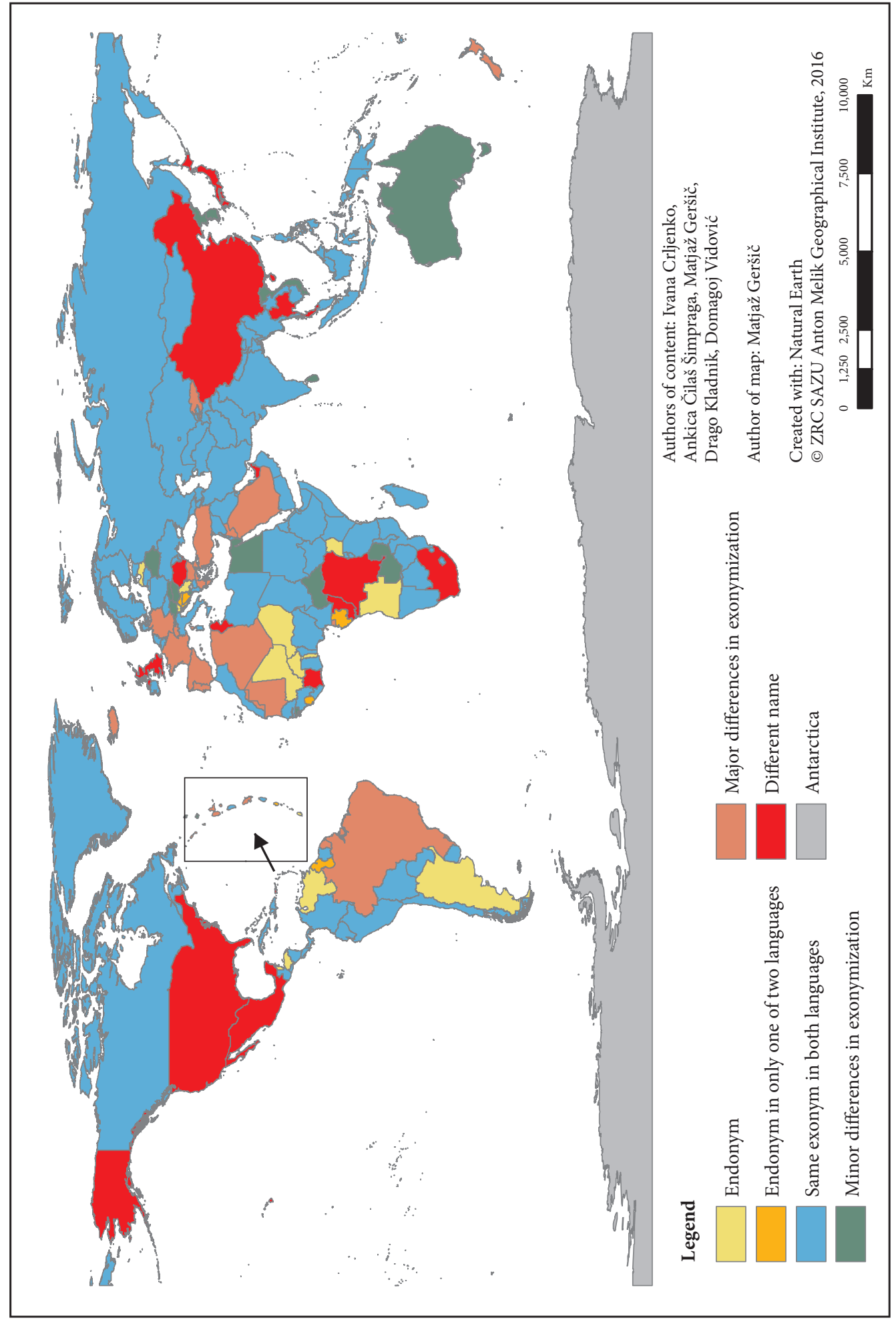




\section{Conclusion}

Detailed studying of Croatian and Slovenian exonyms provides greater insight into exonymization in two related languages that have nonetheless developed differently under the influence of historical circumstances. The comparison of country names showed that nearly half have the same exonym in both languages, which points to their closely connected linguistic development. One-sixth of the names are completely different, and for the remainder the names contain greater or lesser differences. Endonyms are rarely used in either language.

In this regard, ideas have arisen that similar studies could also be conducted at the multilateral level. Studies including some West Slavic languages, for which lists of exonyms have already been prepared (Hajčiková and Kováčová 1997; Beránek et al. 2006; Internet 2), might prove especially interesting because they would not require any time-consuming systematic collection of exonyms. Within the context of these languages, it would also make sense to compare types of exonymization, considering that this most likely took place in a relatively similar manner.

ACKNOWLEDGEMENT: The Bilateral project BI-HR/14-15-049 was financed by Ministry of Science, Education and Sports of the Republic of Croatia and Slovenian Research Agency.

\section{References}

Beránek, T., Boháč, P., Drápela, V., Harvalik, M., Liščák, V., Šimůnek, R., Šrámek, R. 2006: Index českých exonym. Český úřad zeměměřičský a katastrální. Praha.

Bratec Mrvar, R., Birsak, L., Fridl, J., Kladnik, D., Kunaver, J. 2011: Kocenov srednješolski atlas kot didaktična prelomnica. Geografija Slovenije 22. Ljubljana.

Cigale, M. 1869-1877: Atlant. Ljubljana.

Comrie, B., Matthews, S., Polinsky, M. 1999: Atlas jezikov: Izvor in razvoj jezikov. Ljubljana.

Crljenko, I. 2014: Some older sources for Croatian exonyms analysis. Acta geographica Slovenica 54-1. DOI: http://dx.doi.org/10.3986/AGS54105

Crljenko, I. 2016: Dealing with exonyms in Croatia. UNGEGN Bulletin 50. New York.

Fridl, J., Kladnik, D., Orožen Adamič, M., Perko, D., Urbanc, M. (eds.) 2005: Atlant. Faksimile. Ljubljana.

Hajčiková, M., Kováčová, M. 1997: Slovenské vžité názvy geografických objektov ležiacich mimo územia Slovenskej republiky = Slovak exonyms of geographical features lying out of the territory of the Slovak Republik. Úrad geodézie, kartografie a katastra Slovenskej republiky v Geodetickom a kartografickom ústave Bratislava.

Internet 1: http://ungegn.zrc-sazu.si/Downloads/THEGAZETTEEROFSLOVENIANEXONYMS.aspx (22.4.2015).

Internet 2: http://ksng.gugik.gov.pl/wydawnictwa_ngs.php (23.4.2015).

Kadmon, N. 1997: Toponymy: The lore, laws and language of geographical names. New York.

Kladnik, D. 2007: Characteristics of exonym use in selected European languages. Acta geographica Slovenica 47-2. DOI: http://dx.doi.org/10.3986/AGS47203

Kladnik, D. 2009: Semantic Demarcation of the Concepts of Endonym and Exonym. Acta geographica Slovenica 49-2. DOI: http://dx.doi.org/10.3986/AGS49206

Kladnik, D. 2015: 17. srečanje Delovne skupine za eksonime. Geografski vestnik 87-1.

Kladnik, D., Bole, D. 2012: The Life of Slovenian Exonyms and Their Familiarity in the Professional Community. Acta geographica Slovenica 52-2. DOI: http://dx.doi.org/10.3986/AGS52204

Kladnik, D., Ciglič, R., Hrvatin, M., Perko, D., Repolusk, P., Volk, M. 2013: Slovenski eksonimi. Geografija Slovenije 24. Ljubljana.

Kladnik, D., Perko, D. 2013: Explanatory notes on the gazetteer of Slovenian exonyms. Internet: http://giam2.zrc-sazu.si/sites/default/files/introductory_notes_0.pdf (25.4. 2015).

Perko, D., Kladnik, D. 2017: Slovenian exonyms in North America. Acta geographica Slovenica 57-1. DOI: http://dx.doi.org/10.3986/AGS.4777

Kladnik, D., Geršič, M. 2014: A gazetteer of Slovenian exonyms. The Quest for Definition - Proceedings of the 14th UNGEGN Working Group on Exonyms Meeting, Corfu, 23-25 May 2013. Hamburg. 
Kozen, B. 1887: Kozenov geografijski atlas za srednje škole. Zagreb.

Moder, J. 1972: O pisavi in izreki zemljepisnih imen. Veliki atlas sveta. Ljubljana.

Šekli, M. 2013: Genetolingvistična klasifikacija južnoslovanskih jezikov. Slovensko in slovansko, Jezikoslovni zapiski 19-1.

Weber, T. 2013: Zgodovinski atlas sveta od prazgodovine do 21. stoletja. Ljubljana. 